\title{
Rancangan Penempatan Modul Surya dan Simulasi PLTS Fotovoltaik Atap Gedung RSPTN Rumah Sakit Universitas Udayana
}

\author{
K. H. Merta ${ }^{1}$, I. N. S. Kumara ${ }^{2}$, W. G. Ariastina ${ }^{3}$ \\ Submission: 15-08-2019, Accepted: 15-09-2019
}

\begin{abstract}
Indonesia consumed large amount of electrical energy which mostly generated using conventional resources which was dimisihing. Therefore, government released national energy policy aimed at reducing the use of fossil-based energy and increasing the role of renewable energy. One of the renewable energy source was solar photovoltaic. Udayana University had the potential to develop photovoltaic system on all of its premises and one of them was Udayana Hospital. In this research, a study on the potential of rooftop $P V$ at Udayana University Hospital was presented. It was found that the hospital had the potential to generate total electrical power of $835,560 \mathrm{Wp}$. Our study showed that Building \#1 can potentialy generate 142,560 Wp on its rooftop which capable to supply $31.32 \%$ of energy consumption in the building. It was found Building \#1 could produce energy of arround 166,407 $\mathrm{kWh}$ annualy that was equal to $22.6 \%$ of the electrical energy consumption of the building. By incorporating the roof of ground car parking canopy, the PV system could generate total power of $226,710 \mathrm{Wp}$ which was equal to $46.98 \%$ of Building \#1 total power when it was fully operational. It was estimated that this the combination of rooftop and parking $P V$ could generate energy of 249,610 $\mathrm{kWh}$ annualy which was equal to $32.8 \%$ of the electric energy consumption of Building \#1.
\end{abstract}

Intisari-Indonesia membutuhkan energi listrik yang tinggi tetapi bahan bakar fosil sudah semakin sedikit. Pemerintah mengatasi kondisi tersebut dengan kebijakan energi nasional yang bertujuan mengurangi penggunaan energi fosil dan meningkatkan peran Energi Baru dan Terbarukan. Salah satu sumber energi terbarukan adalah energi surya. Universitas Udayana memiliki potensi untuk mengembangkan PLTS di Rumah Sakit Perguruan Tinggi Negeri Universitas Udayana. Dalam paper ini, dilakukan pengkajian pengembangan PLTS pada RSPTN Universitas Udayana. Didapatkan bahwa RSPTN Universitas Udayana berpotensi menghasilkan daya listrik sebesar 835,560 Wp. PLTS pada atap Gedung \#1 menghasilkan $142,560 \mathrm{Wp}$ yang mampu mensuplai $31.32 \%$ dari total daya jika Gedung \#1 sudah beroperasi penuh. PLTS juga menghasilkan energi sebesar 166,407 $\mathrm{kWh}$ per tahun yang mampu mensuplai $22.6 \%$ dari konsumsi energi listrik Gedung \#1. PLTS pada atap Gedung \#1 dan atap parkir menghasilkan 226,710 Wp yang mampu mensulpai $46.98 \%$ dari total daya jika Gedung \#1 sudah beroperasi penuh. PLTS juga menghasilkan energi sebesar 249,610 kWh per tahun yang mampu mensuplai $32.8 \%$ dari konsumsi energi listrik Gedung \#1.

${ }^{1}$ Mahasiswa, PS Teknik Elektro, Fakultas Teknik, Universitas Udayana, Jl. Kampus Unud Bukit Jimbaran, Bali, 80361, Telepone: 0361-555225; fax: 0361-4321982; e-mail: hari_merta@student.unud.ac.id)

${ }^{2,3}$ Dosen, PS Teknik Elektro, Fakultas Teknik Universitas Udayana, Jln. Kampus Bukit Jimbaran 80361 INDONESIA (telp: 0361-703315; fax: 0361-4321; e-mail: satya.kumara@unud.ac.id)
Kata Kunci- energi terbarukan, listrik matahari, PLTS, rooftop $P V$, fotovoltaik, atap gedung, produki energi, $P V W a t t s$

\section{PENDAHULUAN}

Indonesia sedang menghadapi tantangan dalam penyediaan energi listrik karena kebutuhan energi listrik di Indonesia yang semakin tinggi seiring dengan meningkatnya penggunaan peralatan listrik dan perluasan akses bagi masyarakat yang belum mendapatkan listrik. Sementara itu, bahan bakar fosil yang merupakan sumber energi utama dalam pembangkitan listrik di Indonesia sudah semakin menipis [1]. Pemerintah sudah berusaha mengatasi kondisi energi tersebut dengan mengeluarkan Kebijakan Energi Nasional (KEN). Salah satu tujuan dari kebijakan energi nasional adalah untuk mengurangi penggunaan energi fosil secara bertahap dalam rangka mewujudkan ketersediaan energi nasional. Sasaran ke depan adalah meningkatnya peran Energi Baru dan Terbarukan (EBT) menjadi sekitar 23\% pada tahun 2025 dan naik lagi menjadi lebih dari $31 \%$ pada tahun 2050 [2]. Salah satu sumber energi terbarukan yang berpotensi untuk diterapkan di Indonesia adalah energi surya. Potensi energi surya di Indonesia mencapai $4.8 \mathrm{kWh} / \mathrm{m}^{2}$. Pemerintah sudah mengeluarkan roadmap pemanfaatan energi surya yang menargetkan kapasitas PLTS terpasang pada tahun 2025 adalah $6500 \mathrm{MW}$.

Pulau Bali merupakan salah satu pulau pariwisata Indonesia yang sudah mulai menggunakan PLTS. Pada tahun 2013, dua PLTS skala besar berkapasitas 1 MW dibangun oleh pemerintah pusat di Kabupaten Karangasem dan Kabupaten Bangli yang memerlukan lahan seluas 1,2 hektar. Pada waktu yang sama, enam PLTS stand-alone berkapasitas $15 \mathrm{~kW}$ juga dipasang diberbagai lokasi di Bali. Masyarakat Bali juga sudah mengaplikasikan Solar Home System (SHS) untuk kebutuhan penerangan masyarakat di desa terpencil yang belum terjangkau oleh jaringan distribusi tegangan rendah milik PLN. Ke depan, pemangku kepentingan energi harus ikut serta dalam mendukung pencapaian target EBT. Salah satu hal yang bisa dilakukan adalah dengan membangun PLTS secara swadaya untuk mengurangi ketergantungan energi listrik dari PLN [4][5].

Berdasarkan latar belakang tersebut, dalam penelitian ini dilakukan studi pemanfaatan PLTS sebagai catu daya untuk memenuhi kebutuhan energi listrik di bangunan Rumah Sakit Perguruan Tinggi Negeri (RSPTN) Universitas Udayana. Hal ini merupakan upaya Universitas Udayana untuk mendukung program nasional pengembangan EBT. 


\section{PEMBANGKIT LISTRIK TENAGA SURYA}

\section{A. Teknologi Pembangkit Listrik Tenaga Surya}

PLTS adalah suatu pembangkit listrik yang mengubah sinar matahari menjadi listrik. Komponen utama PLTS adalah modul surya, charger controler, inverter dan baterai. Modul surya merupakan alat konversi energi yang dapat merubah cahaya matahari menjadi arus listrik. Charger controler berfungsi untuk mengatur pengisian arus listrik dari modul surya ke baterai agar baterai terhindar dari pengisian ulang yang berlebihan (overcharged). Inverter merupakan perangkat elektrik yang digunakan untuk mengubah arus listrik searah (DC) menjadi arus listrik bolak balik (AC). Baterai merupakan media penyimpan arus listrik [6].

\section{B. Rooftop PV Solusi Efektif Mobilisasi PLTS Masyarakat}

Rooftop PV merupakan PLTS yang dipasang pada atap bangunan. PLTS yang dipasang pada atap memiliki beberapa keuntungan sebagai berikut [7]:

1. Tersedianya ruang untuk struktur pemasangan PV, sehingga tidak ada lahan tambahan yang diperlukan.

2. Jaringan distribusi sudah ada dan tidak ada koneksi baru yang diperlukan.

3. Beragam ukuran dapat diakomodasi dari $\mathrm{kW}$ untuk perumahan dan MW untuk komersial dan industry.

4. Daya yang dihasilkan digunakan di tempat yang sama sehingga, keterlibatan transmisi dan distribusi lebih sedikit.

5. Kelebihan listrik yang dihasilkan dari PLTS dapat diinjeksi ke dalam jaringan distribusi.

\section{Program Nasional Tentang EBT}

Indonesia memiliki Potensi EBT yang cukup besar diantaranya, mini/mikrohidro sebesar $450 \mathrm{MW}$, biomassa 50 $\mathrm{GW}$, energi surya $4,80 \mathrm{kWh} / \mathrm{m} 2 / \mathrm{hari}$, energi angin 3-6 m/det dan energi nuklir $3 \mathrm{GW}$ [8]. Untuk pengembangan EBT, pemerintah sudah menerbitkan serangkaian kebijakan dan regulasi yang mencakup Peraturan Presiden No. 5/2006 tentang Kebijakan Energi Nasional, Undang-undang No. 30/2007 tentang energi, Undang-undang No. 15/1985 tentang ketenagalistrikan, Permen ESDM No. 002/2006 tentang Pengusahaan Pembangkit Listrik Tenaga Energi Terbarukan Skala Menengah, Kepmen ESDM No. 1122K/30/MEM/2002 tentang Pembangkit Skala Kecil tersebar dan Permen ESDM Nomor 19 Tahun 2016 tentang pembelian tenaga listrik dari PLTS oleh PLN. Saat ini sedang disusun RPP Energi Baru Terbarukan yang berisi pengaturan kewajiban penyediaan dan pemanfaatan energi baru dan energi terbarukan dan pemberian kemudahan serta insentif [3]. Walaupun begitu, kemajuan yang dicapai dalam pembangunan PLTS baik secara nasional dan juga di Bali kondisinya masih jauh dari target yang ditetapkan pemerintah [9].

Dalam program kelistrikan 35.000 MW, PLTS memiliki peran 5.000 MW. Untuk mencapai target tersebut, Kementerian ESDM akan memberikan tarif yang menarik bagi investor melalui Peraturan Menteri ESDM Nomor 19 Tahun 2016 tentang pembelian tenaga listrik dari PLTS oleh PLN [9]. Pengembangan energi surya mencakup pemanfaatan
PLTS di perdesaan dan perkotaan, mendorong komersialisasi PLTS dengan memaksimalkan keterlibatan swasta, mengembangkan industri PLTS dalam negeri, dan mendorong terciptanya sistem dan pola pendanaan yang efisien dengan melibatkan dunia perbankan [10].

\section{Simulator PLTS}

Terdapat banyak aplikasi yang dapat digunakan untuk menghitung energi yang dihasilkan PLTS, salah satunya adalah PVWatts. PVWatts dikembangkan oleh National Renewable Energy Laboratory (NREL) Amerika Serikat. Salah satu keunggulan dari PVWatts adalah kemampuan untuk mengukur produksi energi listrik PLTS dari atap, karena terdapat fitur untuk memasukkan arah dan sudut kemiringan dari atap untuk menyesuaikan hasil produksi energi listrik. PVWatts juga memiliki solar resource yang akurat untuk beberapa daerah tertentu dan pengguna bisa mengatur nilai parameter dari PLTS yang akan digunakan. Parameter yang bisa disesuaikan oleh pengguna meliputi: DC system size (kW), modul type, array type, system losses (\%), tilt (deg), dan azimuth (deg). Parameter losses pada PVWatts juga sangat lengkap meliputi: soiling, shading, snow, mismatch, wiring, connections, light-induced degradation, name plate rating, age, dan availability [11].

\section{METODE PENELITIAN}

Penelitian tentang perancangan PLTS ini dilakukan di komplek gedung rumah sakit milik Universitas Udayana yang disebut Rumah Sakit Perguruan Tinggi Negeri (RSPTN) Universitas Udayana yang berada di Bukit Jimbaran. Data yang digunakan bersumber dari datasheet komponen PLTS yang akan digunakan, data instalasi Mechanical Electrical Plumbing (MEP) RSPTN Universitas Udayana, data profil beban Automatic Meter Reading (AMR) yang didapat dari PLN, data pengukuran intensitas matahari. Untuk memperkirakan energi yang dihasilkan PLTS, digunakan simulator PVWatts. Hasil PVWatts kemudian dibandingkan dengan kondisi pembebanan gedung RSPTN. Gambar 1 memperlihatkan skematik metodologi penelitian. Audit energi dilaksanakan untuk mengetahui bagaimana kondisi sistem kelistrikan, peralatan, dan pola konsumsi energi di RSPTN. Pengukuran iradiasi dilakukan untuk mengetahui potensi energi matahari di lokasi RSPTN.

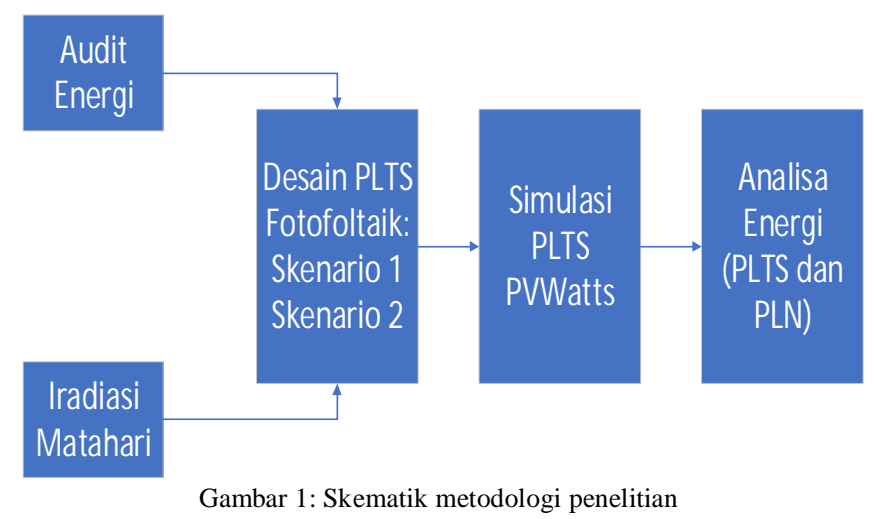




\section{HASIL DAN PEMBAHASAN}

\section{A. Gambaran Umum Rumah Sakit}

RSPTN Universitas Udayana merupakan rumah sakit baru yang dimiliki oleh Universitas Udayana. Rumah sakit ini dibangun di kawasan Jimbaran, Kuta Selatan, Badung, Bali. Rumah Sakit yang dibangun di atas lahan seluas 41,500 m2 ini memiliki 6 bangunan utama yaitu Gedung \#1, Gedung \#2, Gedung \#3, Gedung \#4, Gedung \#5 dan Gedung \#6 seperti terlihat pada gambar 2. Rumah sakit ini mulai dibangun pada tahun 2009 dan masih dalam tahap pembangunan. Gedung yang sudah selesai dibangun dan sudah beroperasi adalah Gedung \#1 dan gedung lainnya masih dalam tahap finishing. Gedung \#1 juga memiliki tempat parkir mobil dan motor yang cukup luas [12].

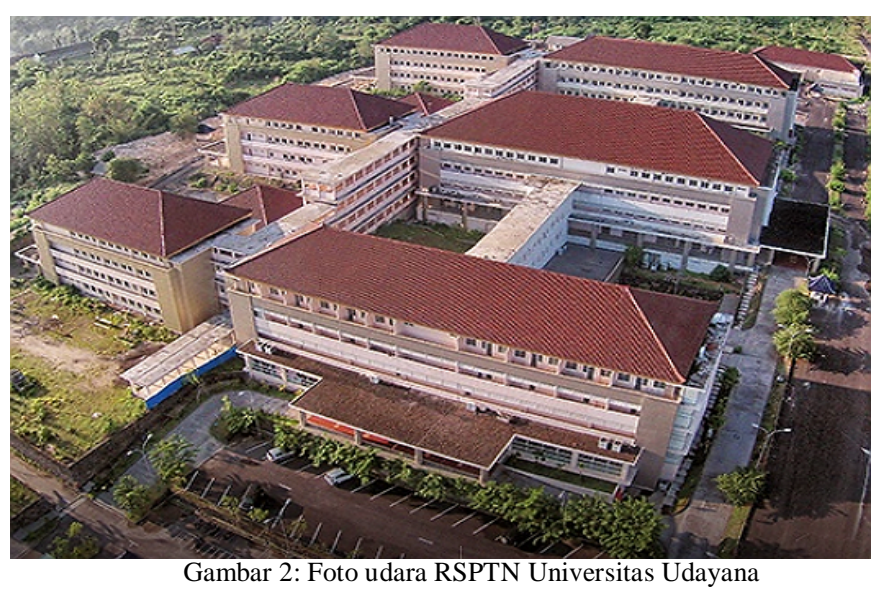

\section{B. Sistem Kelistrikan Gedung \#1}

Daya listrik yang digunakan di Gedung \#1 RSPTN Universitas Udayana berasal dari 2 sumber yaitu dari PLN dan generator set sebagai catu daya backup. Daya listrik PLN menggunakan trafo berkapasitas $1000 \mathrm{kVA}, 20 \mathrm{kV} / 400 \mathrm{~V}$ dan Genset berkapasitas 3 x 380 kVA. Karena keandalan sistem kelistrikan di Bali sudah tinggi maka genset ini sangat jarang dioperasikan. Tetapi karena persyaratan penyediaan tenaga listrik di sebuah rumah sakit yang tidak boleh terputus maka gedung RSPTN dan juga rumah-rumah sakit lainnya harus dilengkapi dengan catu daya emergency yaitu genset. Gambar 3 menunjukkan single line diagram kelistrikan Gedung \#1 [12].

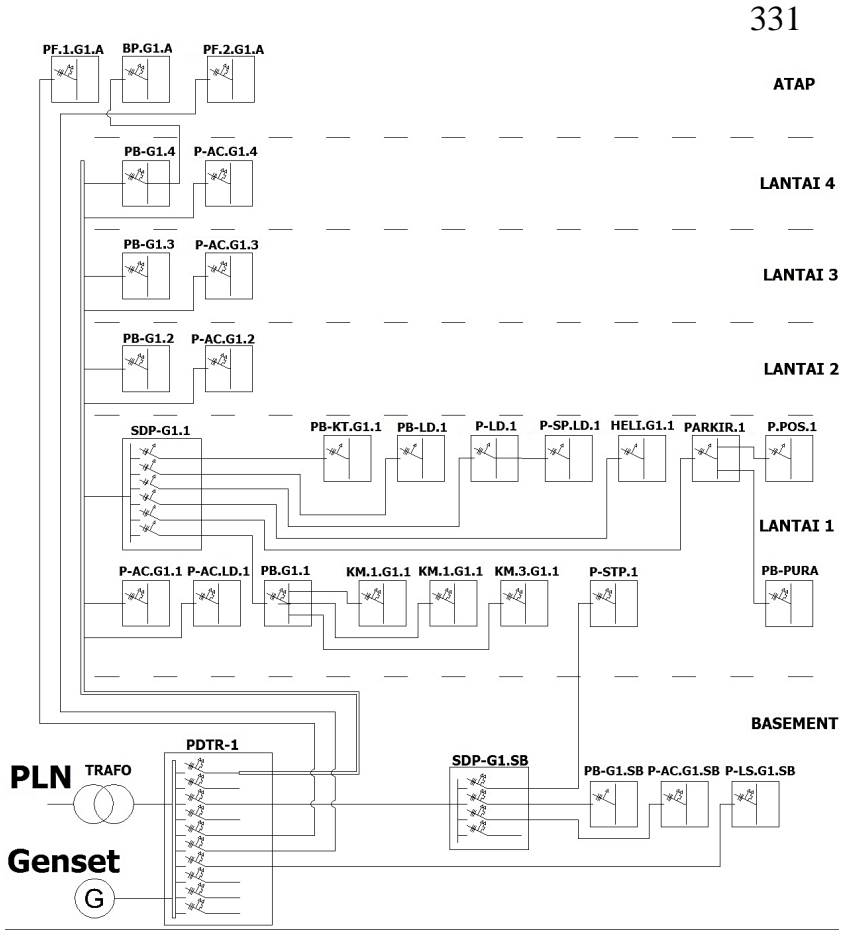

Gambar 3: Single line diagram kelistrikan Gedung \#1

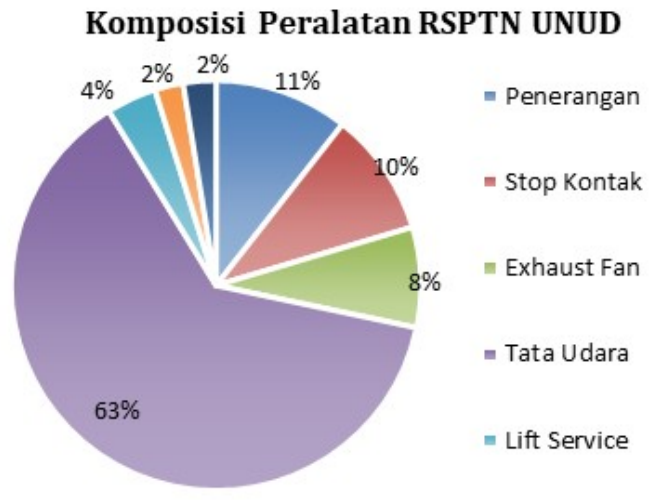

Gambar 4: Peralatan listrik Gedung \#1

Peralatan listrik berdasarkan desain mechanical electrical plumbing (MEP) ditunjukkan pada gambar 4. Dapat dilihat bahwa peralatan tata udara membutuhkan daya paling tinggi yaitu $63 \%$ dari total daya. Sementara itu, fasilitas penerangan $11 \%$, stop kontak $10 \%$, liftservice $4 \%$, peralatan laundry 2 $\%$, peralatan gas medik $2 \%$ dan exhaustfan $8 \%$. Besarnya daya listrik yang dibutuhkan di fasilitas tata udara disebabkan karena banyaknya AC yang digunakan pada Gedung \#1. AC yang digunakan adalah splitduct sebanyak 27 dan splitwall sebanyak 50 [12].

\section{Profil Beban Listrik Rumah Sakit Udayana}


Data profil beban listrik Gedung \#1 diperoleh dari Automatic Meter Reading (AMR) PT. PLN Distribusi Bali dalam rentang waktu 1 tahun dari tanggal 1 Januari 2015 sampai 31 Desember 2015. Gambar 5 merupakan hasil pengukuran daya listrik tertinggi (Watt) setiap bulan dari jam 00.00 sampai 23.30 pada AMR Trafo PLN tahun 2015 dan Gambar 6 merupakan energi yang dikonsumsi Gedung \#1 perbulan pada tahun 2015 [13].

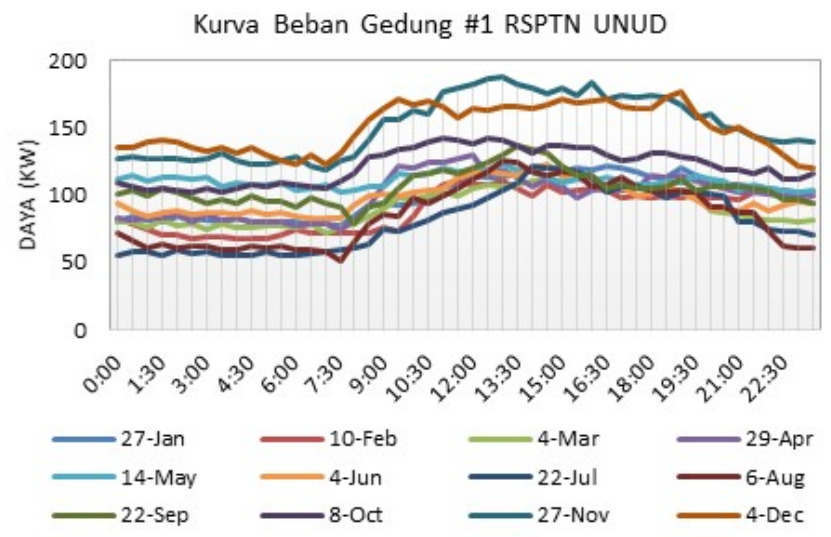

Gambar 5: Kurva beban listrik Gedung \#1 RSPTN UNUD

\section{Penggunaan Energi Gedung \#1 RSPTN UNUD}

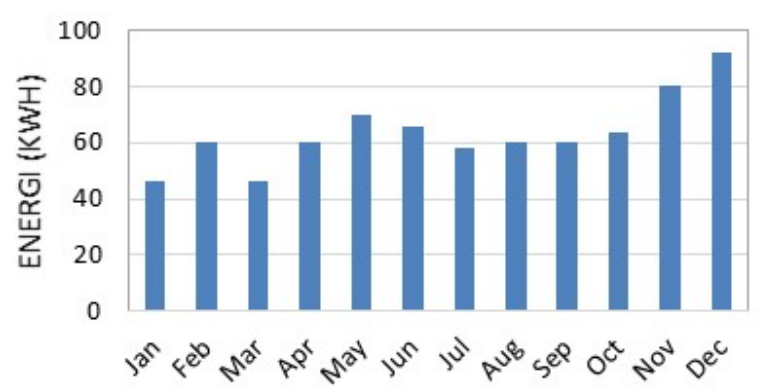

Gambar 6: Profil energi listrik Gedung \#1 RSPTN

\section{Pemilihan Modul Surya}

Luas area pemasangan modul surya dalam penelitian ini dibatasi oleh luas atap Gedung \#1, sehingga untuk mendapatkan output PLTS yang paling besar, modul surya yang akan digunakan dipilih berdasarkan kapasitas tertinggi yang ada di pasaran nasional. Berdasarkan hal tersebut, maka dipilih modul surya dengan spesifikasi $330 \mathrm{~W}$ produksi Kyocera. Pemilihan modul surya produksi Kyocera mengacu pada modul surya yang digunakan di PLTS Microgrid Universitas Udayana - ESDM di Teknik Elektro Universitas Udayana. Tabel I adalah spesifikasi modul surya $330 \mathrm{~W}$ produksi Kyocera [1][14].

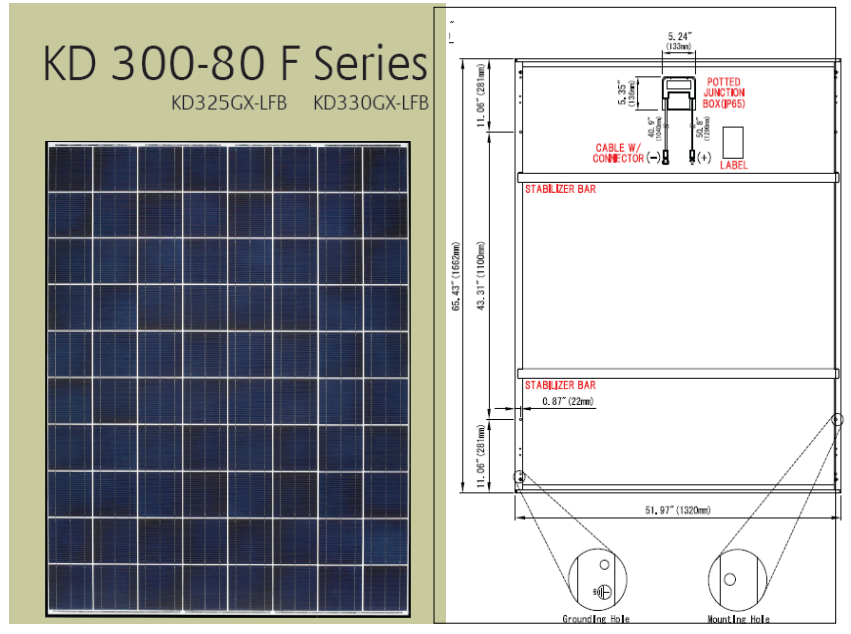

Gambar 7: Modul Surya Kyocera KU330-8BCA

TABEL I

SPESIFIKASI MODUL SURYA

\begin{tabular}{|l|r|}
\hline \multicolumn{1}{|c|}{ Parameter } & \multicolumn{2}{c|}{ Nilai } \\
\hline STC Power Rating (W) & 330 \\
\hline Imp (A) & 7.86 \\
\hline Vmp (V) & 42 \\
\hline Isc (A) & 8.74 \\
\hline Voc (V) & 50.3 \\
\hline Temp. Coefficient of Isc & $0.06 \% / \mathrm{K}$ \\
\hline Temp. Coefficient of Power & $-0.04 \% / \mathrm{K}$ \\
\hline Temp. Coefficient of Voltage & $-0.181 \mathrm{~V} / \mathrm{K}$ \\
\hline Dimension (mm) & $1,622 \times 1,320 \times 46$ \\
\hline Maximum System Voltage (V) & 1000 \\
\hline
\end{tabular}

Dari tabel I diketahui bahwa daya maksimum (Pmax) yang bisa dihasilkan modul surya KU330-8BCA adalah 330W. Tegangan (Vmp) dan Arus (Imp) maksimum yang bisa dihasilkan adalah $42 \mathrm{~V}$ dan $7.86 \mathrm{~A}$. Tegangan open circuit (Voc) dan Arus short circuit (Isc) merupakan tegangan dan arus maksimum yang bisa dihasilkan modul surya saat berada dalam keadaan open circuit.

\section{E. Potensi PLTS Atap Gedung Rumah Sakit Udayana}

Berdasarkan buku MEP tahun 2010, luas atap seluruh Gedung RSPTN Universitas Udayana adalah 7,044 $\mathrm{m}^{2}$. Sementara, luas satu modul surya yang dipilih berdasarkan datasheet adalah $2.19 \mathrm{~m}^{2}$. Jumlah modul surya yang dapat dipasang pada atap dihitung dengan cara membagi luas atap dengan luas modul surya, sehingga didapatkan hasil 2,532. Gambar 8 merupakan gedung RSPTN Universitas Udayana beserta modul surya yang bisa dipasang pada atap. 


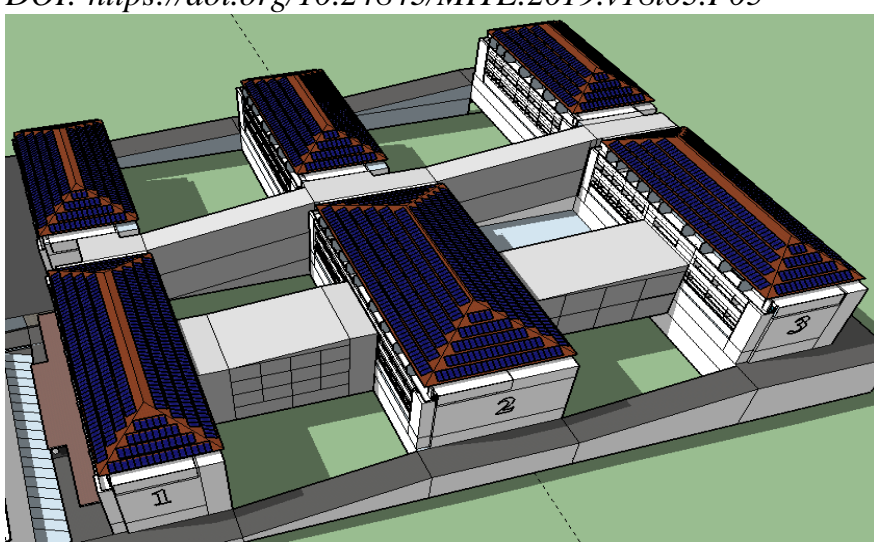

Gambar 8: Modul surya pada atap gedung RSPTN Universitas Udayana

Daya yang bisa dibangkitkan PLTS pada seluruh atap gedung RSPTN Universitas Udayana adalah:

$$
\begin{aligned}
\mathrm{P}(\text { watt peak }) & =\text { jumlah modul } \times \text { kapasitas modul } \\
& =2,502 \times 330 \\
& =825,660 \mathrm{Wp}
\end{aligned}
$$

Jika seluruh atap gedung Rumah Sakit Udayana dipasangi modul surya Kyocera $330 \mathrm{~W}$, maka akan bisa dihasilkan daya maksimum sebesar 825,660 Wp. Seperti dijelaskan di atas bahwa hanya Gedung \#1 saja yang beroperasi, maka perencanaan PLTS dilakukan hanya untuk Gedung \#1 saja. Pendekatan yang sama bisa dilakukan untuk gedung-gedung yg lain. Di samping itu, karena adanya tempat parkir, maka akan dilakukan juga perhitungan potensi pemasangan modul surya di atas tempat parkir tersebut.

\section{F. Perhitungan Daya dan Energi PLTS pada Skenario 1}

Software SketchUp digunakan untuk mempermudah perhitungan luas atap dan scenario. Terdapat 2 skenario yang akan digunakan yaitu: skenario 1 adalah PLTS dipasang di atap Gedung \#1 dan skenario 2 adalah PLTS dipasang di atap Gedung \#1 dan di atap parkir. Untuk memperkirakan besarnya produksi energi listrik dari PLTS yang dirancang, akan dihitung menggunakan PVWatts. Pada Skenario 1, PLTS dipasang di atap Gedung \#1. Berdasarkan data pada buku MEP RSPTN Universitas Udayana tahun 2010, luas atap Gedung \#1 adalah $1,268 \mathrm{~m}^{2}$. Sehingga, modul surya yg bisa dipasang pada atap Gedung \#1 adalah 432.

K. H. Merta: Rancangan dan Simulasi PLTS Fotovoltaik(...)

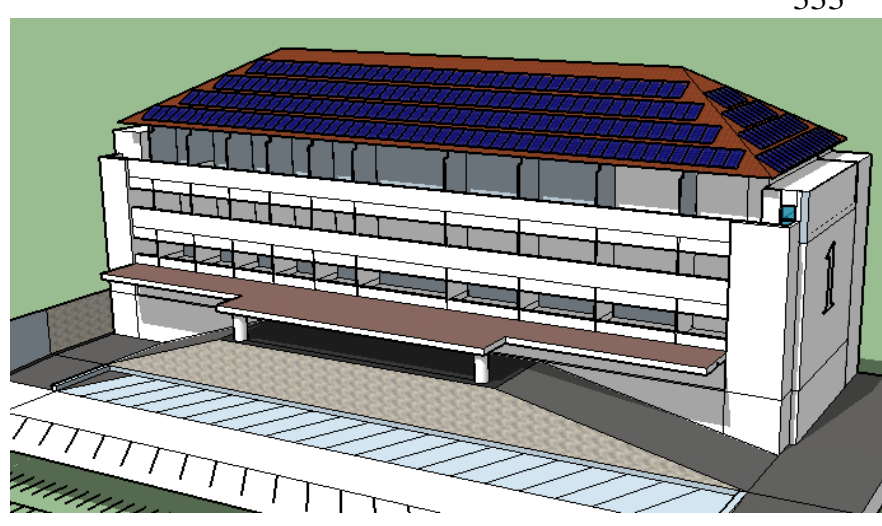

Gambar 9: Modul surya yg bisa dipasang pada atap Gedung \#1

Besarnya daya yang bisa dibangkitkan PLTS, dapat diketahui dengan persamaan berikut:

$$
\begin{aligned}
\mathrm{P}(\mathrm{Wp}) & =\text { jumlah modul } \times \text { kapasitas modul } \\
& =432 \times 330 \\
& =142,560 \mathrm{Wp}
\end{aligned}
$$

Daya listrik maksimum yang digunakan Gedung \#1 RSPTN Universitas Udayana berdasarkan data AMR tahun 2015 adalah 183,680 Watt. Jika dibandingkan dengan daya yang dihasilkan PLTS pada skenario 1, maka PLTS mampu mensuplai $76.77 \%$ dari konsumsi daya listrik tertinggi. Berdasarkan data pada buku MEP RSPTN Universitas Udayana Gedung \#1, total daya yang dibutuhkan jika Gedung \#1 sudah beroperasi penuh adalah 455,151 Watt. Sehingga, daya listrik PLTS yang sebesar 142,560 Watt bisa mensuplai $31.32 \%$ dari total daya jika Gedung \#1 sudah beroperasi penuh.

\section{G. Perhitungan PVWatts}

PVWatts memerlukan 6 input untuk mendapatkan hasil perhitungan besarnya produksi energi dari PLTS, yaitu: DC system size ( $\mathrm{kW})$, modul type, array type, system losses (\%), tilt (deg), dan azimuth (deg). Di samping itu, perlu juga dipilih data meteorologi yang akan digunakan. Pemilihan ini didasarkan atas lokasi penelitian. Database tentang kondisi radiasi matahari dan meteorologi dipilih berdasarkan daerah yang akan digunakan. Jika daerah yang dipilih tidak tersedia database, maka database bisa dipilih secara manual berdasarkan kemiripan karakteristik kondisi radiasi matahari dan meteorologi. Daerah Jimbaran, Bali belum memiliki database pada PVWatts, sehingga PVWatts memilih database daerah Sarawak, Malaysia secara otomatis. Dari segi kondisi radiasi matahari dan meteorologi, database pada daerah Sarawak, Malaysia kurang sesuai dengan daerah Jimbaran, Bali. Sehingga, berdasarkan kemiripan karakteristik kondisi radiasi matahari dan meteorologi database yang digunakan adalah database pada daerah Darwin, Australia. 


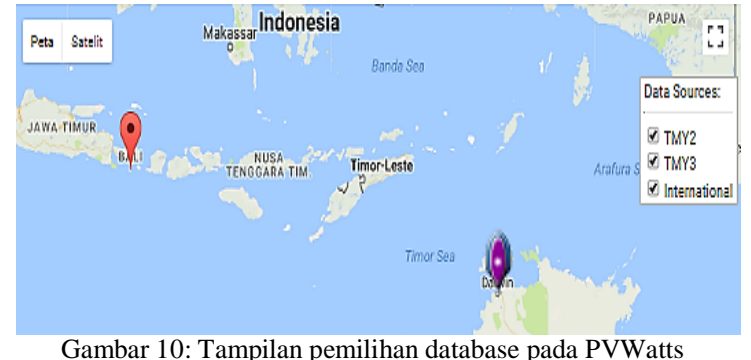

Curah Hujan Pada Lokasi Sumber Data Meterologi

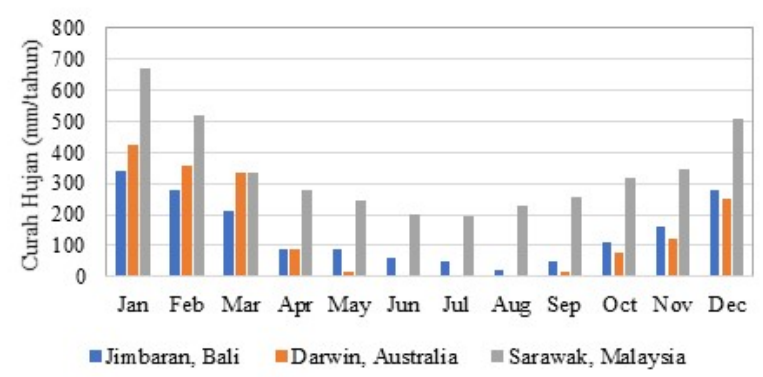

Gambar 11: Grafik curah hujan Jimbaran, Darwin dan Sarawak

\section{Perbandingan Suhu Sumber Data Meterologi}

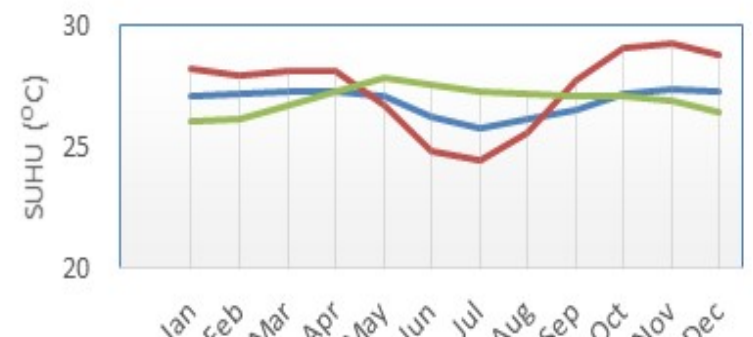

Jimbaran, Bali _Darwin, Australia __ Sarawak, Malaysia

Gambar 12: Grafik suhu Jimbaran, Darwin dan Sarawak

Pada menu System Info terdapat 6 parameter yang harus diisi. Pada DC System Size diisi besarnya total daya output dari PLTS. Sesuai dengan perencaanaan PLTS pada skenario 1, besarnya total daya output PLTS adalah 142,560 Wp dengan tipe modul standard sesuai dengan modul yang akan digunakan dan azimuth $30^{\circ}$ sesuai dengan sudut azimuth Gedung \#1. Sudut kemiringan modul surya dihitung berdasarkan persamaan berikut [1]:

$$
\begin{aligned}
\alpha & =90^{\circ}+\text { lat }-\delta \\
& =90^{\circ}+8.78^{\circ}-23.45^{\circ} \\
& =75.33^{\circ} \\
\beta & =90^{\circ}-\alpha \\
& =90^{\circ}-75.33^{\circ} \\
& =14.67^{\circ}
\end{aligned}
$$

TABEL II

DATA INPUT PVWATTS

\begin{tabular}{|l|r|}
\hline \multicolumn{1}{|c|}{ Description } & \multicolumn{2}{|c|}{ Value } \\
\hline DC System Size $(\mathrm{kW})$ & 142.56 \\
\hline Module Type & Standard \\
\hline Array Type & Fixed (roof mount) \\
\hline System Losses $(\%)$ & 35.92 \\
\hline Tilt $(\mathrm{deg})$ & 14.67 \\
\hline Azimuth $(\mathrm{deg})$ & 30 \\
\hline
\end{tabular}

Pada menu System Losses, terdapat 10 parameter yang menentukan besarnya losses pada PLTS. Parameter yang dipilih mengacu pada kondisi di lapangan Gedung \#1 RSPTN Universitas Udayana. Untuk parameter losses pada soiling, digunakan nilai asumsi 5.48\%. Nilai ini mengacu pada penelitian yang dilakukan oleh Putu Ariesta Sujana pada tahun 2015 tentang Pengaruh Kebersihan Modul Surya Terhadap Unjuk Kerja PLTS [15]. Pada parameter shading, digunakan asumsi $25 \%$.

TABEL III

PERBANDINGAN ENERGI LISTRIK PADA SKENARIO 1

\begin{tabular}{|l|r|r|r|}
\hline Month & $\begin{array}{c}\text { PVWatts } \\
(\mathbf{k W h})\end{array}$ & $\begin{array}{c}\text { Consumtion } \\
(\mathbf{k W h})\end{array}$ & $\begin{array}{r}\text { Persentase PLTS } \\
(\%)\end{array}$ \\
\hline Jan & 12.46 & 46 & 27.1 \\
\hline Feb & 11.43 & 60 & 19.1 \\
\hline Mar & 13.66 & 46 & 29.7 \\
\hline Apr & 12.86 & 60 & 21.4 \\
\hline May & 14.52 & 70 & 20.7 \\
\hline Jun & 13.46 & 66 & 20.4 \\
\hline Jul & 14.41 & 58 & 24.8 \\
\hline Aug & 15.73 & 60 & 26.2 \\
\hline Sep & 15.59 & 60 & 26.0 \\
\hline Oct & 15.79 & 64 & 24.7 \\
\hline Nov & 14.41 & 80 & 18.0 \\
\hline Dec & 12.43 & 92 & 13.5 \\
\hline
\end{tabular}

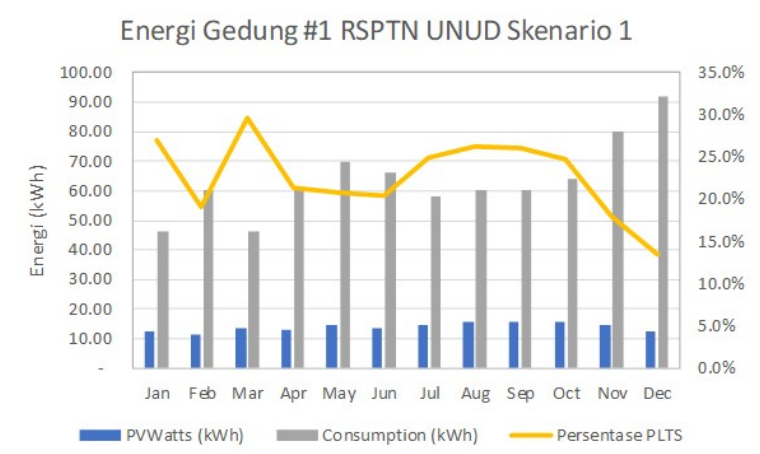

Gambar 13: Produksi energi simulasi PVWatts Skenario 1

Data energi listrik Gedung \#1 RSPTN Universitas Udayana pada tabel III berdasarkan data invoice pembayaran rekening listrik PLN tahun 2015. Energi listrik yang dihasilkan PLTS mampu mensuplai $22.6 \%$ dari konsumsi energi listrik Gedung \#1 RSPTN Universitas Udayana. 


\section{H. Perhitungan daya dan energi PLTS pada Skenario 2}

Pada Skenario 2, PLTS dipasang di atap Gedung \#1 dan atap parkir. Modul surya yang bisa dipasang pada atap Gedung \#1 adalah 432 dan modul surya yang bisa dipasang pada atap parkir adalah 216, sehingga total modul surya yang bisa dipasang adalah 648 .

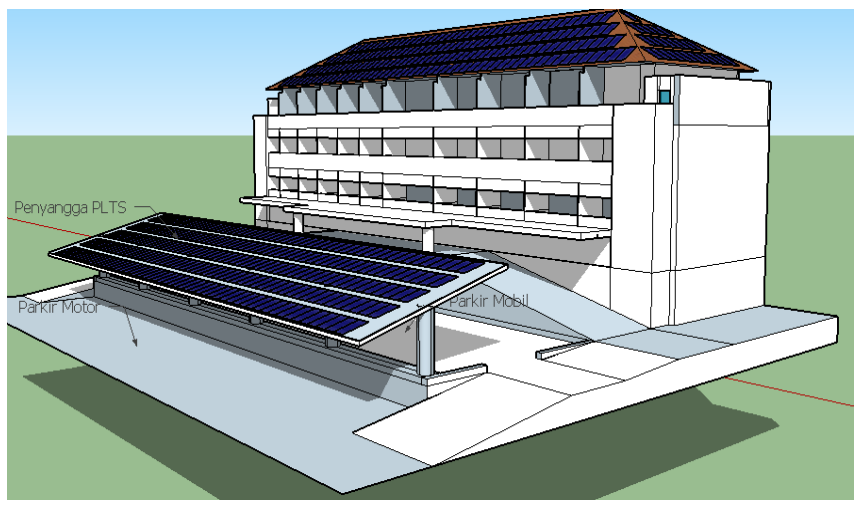

Gambar 14: Atap parkir dan atap Gedung \#1 yang dipasang modul surya

Besarnya daya yang bisa dibangkitkan PLTS, dapat diketahui dengan persamaan berikut:

$$
\begin{aligned}
\mathrm{P}(\text { watt peak }) & =\text { jumlah modul } \times \text { kapasitas modul } \\
& =648 \times 330 \\
& =213,840 \mathrm{Wp}
\end{aligned}
$$

Total daya output PLTS skenario 2 sebesar 213,840 Wp mampu mensuplai $116.41 \%$ dari konsumsi daya listrik tertinggi yang sebesar 183,680 Watt dan juga mampu mensuplai $46.98 \%$ dari total daya jika Gedung \#1 sudah beroperasi penuh yang sebesar 455,151 Watt.

\section{Perhitungan PVWatts}

Langkah-langkah penggunaan PVWatts pada skenario 2 hampir sama dengan skenario 1. yang membedakan adalah nilai pada DC System Size $(\mathrm{kW})$ di System Info. Tabel IV menampilkan System Info PVWatts untuk Skenario 2.

TABEL IV

PERBANDINGAN ENERGI LISTRIK PADA SKENARIO 2

\begin{tabular}{|l|r|}
\hline \multicolumn{1}{|c|}{ Description } & \multicolumn{1}{c|}{ Value } \\
\hline DC System Size (kW) & 213.84 \\
\hline Module Type & Standard \\
\hline Array Type & Fixed (roof mount) \\
\hline System Losses $(\%)$ & 35.92 \\
\hline Tilt $(\mathrm{deg})$ & 14.67 \\
\hline Azimuth $(\mathrm{deg})$ & 30 \\
\hline
\end{tabular}

Hasil perhitungan PVWatts untuk skenario 2 dapat dilihat pada tabel $\mathrm{V}$.

\section{TABEL V}

K. H. Merta: Rancangan dan Simulasi PLTS Fotovoltaik(...)
PERBANDINGAN ENERGI LISTRIK PADA SKENARIO 2

\begin{tabular}{|l|r|r|}
\hline Month & $\begin{array}{c}\text { Solar } \\
\text { Radiation } \\
\text { (kWh/m2/d) }\end{array}$ & $\begin{array}{c}\text { Energy } \\
\text { (kWh) }\end{array}$ \\
\hline Jan & 5.17 & 18,692 \\
\hline Feb & 5.21 & 17,147 \\
\hline Mar & 5.68 & 20,485 \\
\hline Apr & 5.54 & 19,292 \\
\hline May & 6.08 & 21,783 \\
\hline Jun & 5.71 & 20,193 \\
\hline Jul & 5.93 & 21,614 \\
\hline Aug & 5.51 & 23,602 \\
\hline Sep & 5.73 & 23,382 \\
\hline Oct & 5.66 & 23,688 \\
\hline Nov & 5.09 & 21,094 \\
\hline Dec & 5.08 & 18,639 \\
\hline
\end{tabular}

TABEL VI

PERBANDINGAN ENERGI LISTRIK PADA SKENARIO 2

\begin{tabular}{|l|r|r|r|}
\hline Month & $\begin{array}{c}\text { PVWatts } \\
(\mathbf{k W h})\end{array}$ & $\begin{array}{c}\text { Consumtion } \\
(\mathbf{k W h})\end{array}$ & $\begin{array}{c}\text { Persentase PLTS } \\
(\boldsymbol{\%})\end{array}$ \\
\hline Jan & 18.69 & 46 & 40.6 \\
\hline Feb & 17.15 & 60 & 28.6 \\
\hline Mar & 20.49 & 46 & 44.5 \\
\hline Apr & 19.29 & 60 & 32.2 \\
\hline May & 21.78 & 70 & 31.1 \\
\hline Jun & 20.19 & 66 & 30.6 \\
\hline Jul & 21.61 & 58 & 37.3 \\
\hline Aug & 23.6 & 60 & 39.3 \\
\hline Sep & 23.38 & 60 & 39.0 \\
\hline Oct & 23.69 & 64 & 37.0 \\
\hline Nov & 21.09 & 80 & 26.4 \\
\hline Dec & 18.64 & 92 & 20.3 \\
\hline
\end{tabular}

Dari tabel VI dapat dilihat energi listrik yang dihasilkan PLTS rata-rata mampu mensuplai $32.8 \%$ dari konsumsi energi listrik Gedung \#1 RSPTN Universitas Udayana.

\section{KESIMPULAN}

Dari kajian pemanfaatan PLTS di Rumah Sakit Udayana di atas, dapat diambil beberapa kesimpulan sebagai berikut: Rumah Sakit Udayana memiliki profil beban kelistrikan dimana beban puncak terjadi pada siang hari, sehingga sangat cocok dengan potensi matahari di lokasi yang terjadi antara jam 7 hingga jam 18. Rumah Sakit Universitas Udayana memiliki 6 gedung yang berpotensi menghasilkan daya listrik sebesar 835,560 Wp jika seluruh atap dipasangi modul surya dengan kapasitas $330 \mathrm{~W}$. Penelitian PLTS di RSPTN Universitas Udayana difokuskan pada Gedung \#1 karena dari 6 gedung, hanya Gedung \#1 yang sudah beroperasi dan gedung lainnya masih dalam tahap pembangunan. Jika atap

p-ISSN:1693 - 2951; e-ISSN: 2503-2372 
Gedung \#1 dipasangi modul surya Kyocera 330 W, maka bisa dipasang modul sebanyak 432 buah dengan total daya 142,560 Wp. Jika diestimasi dengan PVWatts maka PLTS Gedung \#1 ini akan mampu menghasilkan energi sebanyak 166,407 kWh per tahun. Energi listrik ini setara dengan $22.6 \%$ dari konsumsi energi listrik di gedung tersebut. Jika atap parkir yang ada juga dipasangi modul surya lalu potensi daya nya ditambah dengan potensi atap Gedung \#1, maka bisa dipasang modul sebanyak 648 buah dengan total daya 226,710 Wp dan energi 249,610 kWh per tahun. Energi listrik ini setara dengan $32.8 \%$ dari total konsumsi energi listrik gedung.

\section{REFERENSI}

[1] S KUMARA, Nyoman. TELAAH TERHADAP PROGRAM PERCEPATAN PEMBANGUNAN LISTRIK MELALUI PEMBANGUNAN PLTU BATUBARA 10.000 MW. Majalah Ilmiah Teknologi Elektro, [S.1.], v. 8, n. 1, aug. 2012. ISSN 2503-2372

[2] KESDM, "Kebijakan Batubara Nasional", Keputusan Menteri Energi dan Sumber Daya Mineral Republik Indonesia Nomor : 1128 K/40/MEM/2004, Jakarta, 2004.

[3] Kumara, N. S., "Pembangkit Listrik Tenaga Surya (PLTS) Skala Rumah Tangga Urban dan Ketersediaannya di Indonesia”, Vol: 9 No.1 hal 71, Universitas Udayana, 2010.

[4] I. N. S. Kumara, W. G. Ariastina, I. W. Sukerayasa and I. A. D. Giriantari, "1 MWp grid connected PV systems in the village of Kayubihi Bali; Review on location's characteristics and its technical specifications," 2013 International Conference on Information
Technology and Electrical Engineering (ICITEE), Yogyakarta, 2013, pp. 306-311. doi: 10.1109/ICITEED.2013.6676258.

[5] Visnu, S. P., "Analisa Unjuk Kerja Pembangkit Listrik Tenaga Surya $15 \mathrm{~kW}$ di Dusun Asah Teben Desa Datah Karangasem", Skripsi, Universitas Udayana, 2015.

[6] Arora, P.R., "Right Time to Reap Benefits from Residential Solar Rooftop PV in India - A Venture of Millions", International Journal of Scientific and Research Publications, Volume 3, Issue 7, July 2013.

[7] KESDM, "Kajian Supply Demand Energy (SDE)", Kementrian Energi dan Sumber Daya Mineral, Jakarta, 2013.

[8] KESDM, "Pembelian Tenaga Listrik dari PLTS Fotovoltaik oleh PLN", Permen ESDM Nomor 19, 2016.

[9] I. N. S. Kumara, W. G. Ariastina, I. W. Sukerayasa and I. A. D. Giriantari, "On the potential and progress of renewable electricity generation in Bali," 2014 6th International Conference on Information Technology and Electrical Engineering (ICITEE), Yogyakarta, 2014, pp. 1-6. doi: 10.1109/ICITEED.2014.7007944.

[10] (2016) PVWatts Calculator website. [Online], http://pvwatts.nrel.gov/. Tanggal akses: 5 Agustus 2016.

[11] MEP, "Mechanical Electrical Plumbing RSPTN Universitas Udayana", MEP, Jimbaran, 2010.

[12] PLN, "Automatic Meter Reading Trafo RSPTN Universitas Udayana", Perusahaan Listrik Negara, Denpasar, 2015.

[13] (2016) Datasheet Kyocera website. [Online], http://solardesigntool.com. Tanggal akses: 6 Agustus 2016.

[14] SUJANA, P.A.; KUMARA, I.N.S.; GIRIANTARI, I.A.D. PENGARUH KEBERSIHAN MODUL SURYA TERHADAP UNJUK KERJA PLTS. Jurnal SPEKTRUM, [S.1.], v. 2, n. 3, p. 49-54, mar. 2016. ISSN 2684-9186. 